CURRENT

Jurnal Kajian Akuntansi dan Bisnis Terkini

https://current.ejournal.unri.ac.id

\title{
PERSEPSI AKUNTAN PUBLIK DAN AKUNTAN PENDIDIK TERHADAP KONSEP DASAR, PENGUKURAN, DAN PENGUNGKAPAN AKUNTANSI LINGKUNGAN
}

\author{
Mela Febri Yanti ${ }^{1}$, Ethika Ethika ${ }^{2}$, Arie Frinola Minovia ${ }^{3 *}$ \\ ${ }^{123}$ Program Studi Akuntansi, Fakultas Ekonomi dan Bisnis, Universitas Bung Hatta, Padang \\ "E-mail: melafebri12@gmail.com
}

\begin{tabular}{l} 
Keywords \\
\hline Public Accountants, \\
Educator Accountants, \\
Basic Concepts of \\
Environmental Accounting, \\
Measurement of \\
Environmental Accounting \\
and Disclosure of \\
Environmental Accounting \\
\hline
\end{tabular}

Article informations

Received:

2020-12-09

Accepted:

2021-07-25

Available Online:

2021-07-31

\begin{abstract}
This study aims to examine empirically the differences in auditors and lecturers' perceptions of basic concepts, measurements and environmental accounting disclosures. This research was conducted at Public Accountants registered at the Indonesian Institute of Public Accountants (IAPI) in Padang City and Accounting Educators who hold accountants at State and Private Universities in Padang City. The sample selection was based on convenience sampling method and finally obtained 31 auditors and 31 lecturers who had met the criteria for sampling. The data analysis technique used to test the hypothesis is the Independent Sample t-Test using SPSS version 16 software. The Results of this study indicate that there are difference in perceptions between public accountants and educating accountants on the basic concepts of accounting, But according to public accountants and educating accountants, there are no differences in the measurement of environmental accounting and environmental accounting disclosures.
\end{abstract}

\section{PENDAHULUAN}

Terjadinya kerusakan lingkungan yang diakibatkan oleh industri mulai banyak dirasakan oleh masayarakat di dunia. Perkembangan sektor industry ditemukan banyak memiliki dampak yang negatif yang mempengaruhi kelestarian lingkungan. Meskipun akuntansi lingkungan telah berkembang sejak lama namun masih terdapat beberapa perusahaan yang tidak menjalankan etika bisnis untuk menjaga kelestarian lingkungan alam dengan membuang limbah pabrik mereka tanpa proses pengelolaan limbah yang berwawasan lingkungan (Aniela, 2012).

Kesuksesan implementasi akuntansi lingkungan tidak hanya tergantung pada ketepatan dalam menggolongkan semua biaya - biaya yang dibuat perusahaan, tetapi juga bergantung pada kemampuan dan keakuratan data akuntansi perusahaan dalam menekan dampak lingkungan yang ditimbulkan dari aktivitas perusahaan. Sebagai 
alat manajemen lingkungan, akuntansi lingkungan digunakan untuk menilai keefektifan kegiatan konservasi berdasarkan ringkasan dan klasifikasi biaya konservasi lingkungan. Data akuntansi lingkungan juga digunakan untuk menentukan biaya fasilitas pengelolaan lingkungan, biaya keseluruhan konservasi lingkungan dan juga investasi yang diperlukan untuk kegiatan pengelolaan lingkungan. Selain itu akuntansi lingkungan juga digunakan untuk menilai tingkat keluaran dan capaian tiap tahun untuk menjamin perbaikan kinerja lingkungan yang harus berlangsung terus menerus (Ikhsan, 2008:1-2).

Pentingnya akuntansi lingkungan pada dasarnya menuntut kesadaran penuh perusahaan - perusahaan maupun organisasi lainnya yang telah mengambil manfaat dari lingkungan. Beberapa alasan kenapa perusahaan perlu mempertimbangkan mengadopsi akuntansi lingkungan sebagai bagian dari sistem akuntansi perusahaan, antara lain memungkinkan untuk mengurangi dan menghapus biaya-biaya lingkungan, memperbaiki kinerja lingkungan perusahaan yang selama ini mungkin mempunyai dampak negatif terhadap kesehatan manusia dan keberhasilan bisnis perusahaan, yang diharapkan menghasilkan biaya atau harga yang lebih akurat terhadap produk dari proses lingkungan yang diinginkan dan memungkinkan pemenuhan kebutuhan pelanggan yang mengharapkan produk atau jasa lingkungan yang lebih bersahabat (Daftar, 2017).

Kesadaran lingkungan merupakan komitmen awal atas komitmen pelestarian lingkungan. Akuntan merupakan profesi penyedia informasi bagi pemangku kepentingan harus memiliki kesadaran lingkungan yang tinggi. Hal ini disebabkan karena akuntan memiliki peran strategis atas aktivitas penyelamatan lingkungan, karena akuntan menyediakan informasi lingkungan yang strategis dalam pengambilan keputusan (Alimbudiono, 2020).

Penurut Alimbudiono (2020) terdapat kesenjangan fenomena berdasarkan temuan yang dilakukannya, bahwa banyak akuntan publik kurang berpengetahuan cukup dalam pelaporan dan audit lingkungan. Selain itu, banyak akuntan merasa bahwa isu lingkungan tidak masuk dalam ranah akuntansi. Kondisi ini mengkhawatirkan, karena tahun 1990, organisasi profesi di Amerika menjelaskan bahwa akuntansi konvensional sudah sangat ketinggalan dan harus berubah. Perubahan dimulai dari pendidikan akuntansi dengan memasukkan beragam unsur sesuai perkembangan bisnis yang modern, termasuk akuntansi lingkungan.

Menurut Menurut USEPA (1995a) dalam Sari dan Nugroho (2017), akuntansi lingkungan mengacu pada identifikasi, kompilasi, pengukuran, analisis, pelaporan dan menggunakan informasi biaya lingkungan dalam proses pengambilan keputusan untuk membantu mengurangi dampak lingkungan karena sistem dan aktivitasnya. Sementara pengukuran akuntansi lingkungan adalah suatu biaya yang terdapat pada akuntansi 
lingkungan yang ditulis dalam bentuk angka-angka atau persentase untuk mempermudah menentukan bagaimana kualitas lingkungan itu baik atau tidaknya.

Pengungkapan akuntansi lingkungan dibanyak negara, termasuk Indonesia masih bersifat voluntary, artinya tidak ada peraturan yang mewajibkan seperti halnya pada penerbitan financial statement (Sari dan Nugroho, 2017).

Fenomena yang terjadi menunjukkan bahwa masih banyak perusahaan tidak peduli dengan masalah lingkungan agar dapat meraih keuntungan. Perusahaan enggan mengeluarkan biaya untuk mengelola limbah perusahaan mereka. Seperti PT GMK dan PT ZXT yang beroperasi di Bandung ditutup karena sudah dua kali membuang limbah yang belum terolah sempurna langsung menuju ke Sungai Citarum, sebelumnya perusahaan tersebut membuang

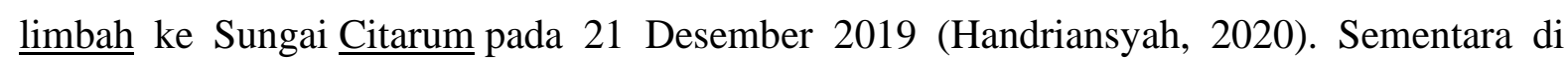
Aceh, PT. Jaya Media Internusa membuang limbah kehulu sungai jambo aye pada malam hari, perusahaan tersebut membuang limbah cair tanpa melalui proses Instalasi Pengolahan Air Limbah (IPAL). Pemkab Aceh Tengah telah memanggil dan menindak tegas pelaku industri PT. JMI yang membuang limbah pabrik tersebut (Charim, 2020).

Berdasarkan gugatan perdata yang dilayangkan Kementerian Kehutanan dan Lingkungan Hidup (LHK) diketahui bahwa terdapat 11 perusahaan dari tahun 2012 sampai 2018 yang bertanggung jawab atas kebakaran hutan dan lahan (karhutla) serta pembalakan liar. Perusahaan tersebut antara lain PT Kallista Alam di Nagan Raya yang bergerak di sektor industri minyak sawit, PT Surya Panen Subur yang juga bergerak di sektor sawit, PT Jatim Jaya Perkasa milik Gama Grup, Anak perusahaan Sampoerna Agro Tbk, National Sago Prima, PT Bumi Mekar Hijau milik grup Sinar Mas, Ricky Kurniawan Putraper sada, Palmina Utama, dan Waringin Agro Jaya, dan PT Merbau Pelalawan Lestari. 11 perusahaan perusak lingkungan tersebut rugikan negara hingga Rp18 Triliun (Putri, 2019).

Penelitian terdahulu Tanihatu (2015) telah mengkaji mengenai presepsi auditor dan akuntan pendidik terhadap konsep dasar akuntansi lingkungan, pengukuran akuntansi lingkungan dan pengungkapan akuntansi lingkungan. Hasil penelitiannya menunjukkan terdapat perbedaan persepsi antara auditor dan akuntan pendidik terhadap konsep dasar, pengukuran dan pengungkapan akuntansi lingkungan. Penelitian yang dilakukan oleh Wiyantoro et al (2011) menunjukkan bahwa terdapat perbedaan persepsi antara akuntan pendidik, auditor dan akuntan manajemen terhadap konsep dasar, pengukuran dan pengungkapan akuntansi lingkungan. Akuntan pendidik secara teori lebih memahami akuntansi lingkungan namun ketika berada dilapangan auditor dan akuntan manajemen 
lebih berpengalaman.

Pada penelitian Setyo et al (2015) terdapat perbedaan persepsi antara akuntan publik dengan akuntan pendidik terhadap konsep dasar, pengukuran dan pengungkapan akuntansi lingkungan. Karena dosen dianggap secara teori telah memahami Konsep Dasar Akuntansi Lingkungan dalam proses pembelajaran berdasarkan pemahaman dan pemikiran yang logis menurut teori yang ada.

Menurut Penelitian sebelumnya oleh Sari dan Nugroho (2017) adalah bahwa persepsi akuntan pendidik dari 3 Perguruan Tinggi di Kota Salatiga, Surakarta dan Semarang terhadap konsep dasar akuntansi lingkungan di Indonesia saat ini masih tergolong sedang. Selanjutnya, rata-rata akuntan pendidik setuju bahwa pengukuran akuntansi lingkungan dapat diukur dengan satuan moneter. Selanjutnya, ratarata akuntan pendidik setuju bahwa biaya-biaya terkait dengan akuntansi lingkungan diungkapkan dalam laporan keuangan. Dengan diungkapkannya biaya-biaya terkait dengan aktivitas lingkungan kedalam laporan keuangan dapat memberikan informasi yang relevan bagi pengambilan keputusan dengan pertimbangan manfaat dan efek dari lingkungan. Berdasarkan hasil tersebut menunjukkan bahwa penelitian mengenai persepsi akuntan publik dan akuntan pendidik terhadap akuntansi lingkungan masih sedikit.

Berdasarkan fenomena yang terjadi dan untuk melihat apakah saat ini masih terdapat perbedaan persepsi antara akuntan mengenai konsep dasar, pengukuran dan pengungkapan akuntansi lingkungan. Membuat penulis tertarik untuk mengangkat kembali dan meneliti permasalahan tentang Akuntansi Lingkungan. Dikarenakan masih sedikitnya informasi yang membahas bagaimana persepsi atau pandangan akuntan terhadap Akuntansi Lingkungan, dan bagaimana pandangan mereka terhadap pengungkapan akuntansi lingkungan apakah perlu diungkapkan untuk masa yang akan datang atau sangat penting diungkapkan setelah melihat perkembangan akhir akhir ini tentang kerusakan lingkungan yang ditimbulkan oleh perusahaan baik disengaja maupun tidak. Pada penelitian ini objek yang akan diteliti yaitu Akuntan Publik dan Akuntan Pendidik yang ada di Padang.

\section{PENGEMBANGAN HIPOTESIS}

\section{Perbedaan Persepsi Akuntan Publik dengan Akuntan Pendidik terhadap Konsep Dasar}

\section{Akuntansi Lingkungan}

Tanihatu (2015) menemukan bahwa Akuntan pendidik lebih memahami tentang konsep dasar akuntansi, sementara pada saat di lapangan Akuntan public lebih memahami akuntansi lingkungan. Hal ini disebabkan Akuntan Pendidik secara teoritis lebih memahami 
konsep konsep teori akuntansi, namun secara praktek masih kurang. Oleh sebab itu terdapat perbedaan persepsi antara auditor dan akuntan pendidik terhadap konsep dasar akuntansi lingkungan, pengukuran akuntansi lingkungan dan pengungkapan akuntansilingkungan. Penelitian Tanihatu (2015) menemukan bahwa akuntan publik dan akuntan pendidik memiliki perbedaan persepsi mengenai konsep dasar akuntansi lingkungan.

Selanjutnya penelitian yang dilakukan oleh Wiyantoro et al (2011) menemukan bahwa terdapat perbedaan persepsi antara akuntan pendidik, auditor dan akuntan manajemen terhadap konsep dasar akuntansi lingkungan. Para auditor umumnya lebih memahami konsep dasar akuntansi lingkungan dibandingkan dengan akuntan pendidik dan akuntan manajemen.

Penelitian sebelumnya Setyo et al (2015) menemukan terdapat perbedaan persepsi antara akuntan publik dengan akuntan pendidik terhadap konsep dasar, pengukuran dan pengungkapan akuntansi lingkungan. Dosen dianggap secara teori telah memahami konsep dasar Akuntansi Lingkungan dalam proses pembelajaran berdasarkan pemahaman dan pemikiran yang logis menurut teori yang ada.

Berdasarkan uraian diatas maka diajukan sebuah hipotesis yaitu:

$\mathrm{H}_{1}$ : Terdapat perbedaan Persepsi Akuntan Publik dengan Akuntan Pendidik terhadap Konsep Dasar Akuntansi Lingkungan.

\section{Perbedaan Persepsi Akuntan Publik dengan Akuntan Pendidikterhadap Pengukuran}

\section{Akuntansi Lingkungan}

Penelitian sebelumnya yang dilakukan oleh Tanihatu (2015) yang meneliti mengenai persepsi auditor dan akuntan pendidik terhadap konsep dasar akuntan silingkungan, pengukuran akuntansi lingkungan dan pengungkapan akuntansi lingkungan menunjukkan terdapat perbedaan persepsi antara auditor dan akuntan pendidik terhadap pengukuran akuntansi lingkungan. Penelitian ini juga didukung oleh Wiyantoro et al (2011) yang menemukan bahwa terdapat perbedaan persepsi antara akuntan pendidik, auditor dan akuntan manajemen terhadap pengukuran akuntansi lingkungan. Para auditor umumnya lebih memahami pengukuran akuntansi lingkungan dibandingkan dengan akuntan pendidik dan akuntan manajemen.

Setyo et al (2015) menemukan bahwa terdapat perbedaan persepsi antara akuntan publik dengan akuntan pendidik terhadap pengukuran akuntansi lingkungan. Dosen 
dianggap secara teori telah memahami pengukuran Akuntansi Lingkungan dalam proses pembelajaran berdasarkan pemahaman dan pemikiran yang logis menurut teori yang ada. Berdasarkan uraian ringkas beberapa hasil penelitian terdahulu maka diajukan sebuah hipotesis yaitu:

\section{H2: Terdapat perbedaan Persepsi Akuntan Publik dengan Akuntan Pendidik terhadap Pengukuran Akuntansi Lingkungan.}

\section{Perbedaan Persepsi Akuntan Publik dengan Akuntan Pendidik terhadapPengungkapan}

\section{Akuntansi Lingkungan}

Penelitian Tanihatu (2015) dan Wiyantoro et al (2011) menemukan bahwa terdapat perbedaan persepsi antara akuntan pendidik, auditor dan akuntan manajemen terhadap pengungkapan akuntansi lingkungan. Para auditor umumnya lebih memaham ipengungkapan akuntansi lingkungan dibandingkan dengan akuntan pendidik dan akuntan manajemen.

Dosen dianggap secara teori telah memahami pengungkapan Akuntansi Lingkungan dalam proses pembelajaran berdasarkan pemahaman dan pemikiran yang logis menurut teori yang ada. Pada penelitian Setyo et al (2015) menemukan bahwa terdapat perbedaan persepsi antara akuntan publik dengan akuntan pendidik terhadap pengungkapan akuntansi lingkungan.

Berdasarkan uraian ringkas beberapa hasil penelitian terdahulu maka diajukan sebuah hipotesis yaitu:

\section{$\mathrm{H}_{3}$ : Terdapat perbedaan Persepsi Akuntan Publik dengan Akuntan Pendidik terhadap Pengungkapan Akuntansi Lingkungan.}

\section{METODE PENELITIAN}

\section{Populasi dan Sampel}

Populasi mengacu kepada keseluruhan kelompok atau orang, kejadian atau hal minat yang ingin peneliti investigasi (Sekaran, 2014). Subjek yang menjadi target dalam penelitian ini adalah seluruh Akuntan Publik yang terdaftar pada Institut Akuntan Publik Indonesia (IAPI) di Kota Padang dan Akuntan Pendidik (Dosen) Akuntansi yang bergelar akuntan pada Perguruan Tinggi Negeri dan Swasta yang berada di Kota Padang. Sehingga populasi dalam penelitian ini adalah Akuntan Publik dan Akuntan Pendidik di Kota Padang. Teknik pengambilan sampel yang digunakan dalam penelitian ini adalah convenience sampling. 


\section{Jenis dan Sumber Data}

Data yang digunakan dalam penelitian ini adalah data primer dari sumber yang tersedia berupa data dari hasil penyebaran kuesioner oleh Akuntan Publik dan Akuntan Pendidik yang berada di Kota Padang. Sumber data penelitian ini diambil secara langsung dan tidak langsung kepada responden yang telah diminta untuk mengisi kuesioner pada penelitian ini.

\section{Definisi Operasional dan Pengukuran Variabel}

\section{Konsep Dasar Akuntansi Lingkungan}

Menurut USEPA (1995a), konsep dasar akuntansi lingkungan mengacu pada identifikasi, kompilasi, pengukuran, analisis, pelaporan dan menggunakan informasi biaya lingkungan dalam proses pengambilan keputusan untuk membantu mengurangi dampak lingkungan karena sistem dan aktivitasnya. Indikator yang digunakan adalah Identifikasi akuntansi lingkungan - Kompilasi akuntansi lingkungan Pengukuran akuntansi lingkungan - Analisis akuntansi lingkungan - Pelaporan akuntansi lingkungan

Untuk mengukur variabel Konsep Dasar Akuntansi lingkungan menggunakan kuesioner yang juga digunakan oleh Wiyantoro (2011) pertanyaan kuesioner Konsep Dasar Akuntansi lingkungan dengan 5 pertanyaan yang terdiri dari 5 skala likert dimana $1=$ SDT (Sangat Tidak Memadai), $2=$ TD (Tidak Memadai), $3=\mathrm{S}$ (Sedang), 4 = M (Memadai), $5=$ SM (Sangat Memadai).

\section{Pengukuran Akuntansi Lingkungan}

Menurut Rusmana (2003) pengukuran akuntansi lingkungan tidak bisa dilepaskan dari pembahasan mengenai biaya lingkungan (environmental cost). Pengukuran biaya lingkungan pada level organisasi masih mungkin untuk dilakukan karena biaya penanganan material, daur ulang material sisa, pengolahan dan pembuangan limbah masih dalam kendali organisasi

Untuk mengukur variabel ini digunakan kuesioner yang juga digunakan oleh Wiyantoro pertanyaan kuesioner pengukuran akuntansi lingkungan dengan 18 pertanyaan yang terdiri dari 5 skala likert dimana $1=$ SDT (Sangat Tidak Memadai), 2 = TD (Tidak Memadai), 3 = S (Sedang), $4=\mathrm{M}$ (Memadai), $5=\mathrm{SM}$ (Sangat Memadai).

\section{Pengungkapan Akuntansi Lingkungan}

Pengungkapan lingkungan adalah pengungkapan informasi yang berkaitan dengan lingkungan di dalam laporan tahunan perusahaan (Patten,2002). Indikator yang digunakan 
diadopsi dari Sari dan Nugroho (2017) adalah kerusakan sumber daya alam, Biaya air pembersih/pembuang limbah. biaya energi ( bahan bakar, listrik, gas), penanganan limbah berbahaya dalam pabrik, pengendalian emisi udara dalam pabrik, pengaruh buruk bagi kesehatan masyarakat, biaya pra pembersih limbah dalam pabrik, biaya perizinan pembuangan limbah , denda dan hukuman terhadap lingkungan, biaya pengetesan/monitoring terhadap limbah, biaya pra pembersihan dan pembuangan limbah cair dalam pabrik, biaya pra pembersih untuk dipindahkan ke tempat pembuangan diluar pabrik, klaim kompensasi keamanan/ kesehatan, pelatihan staff dalam penataan lingkungan, pelaporan kepada badan badan pemerintah, biaya tenaga kerja staff lingkungan dan hukum, biaya konosemen, surat muatan dll.

Untuk mengukur variabel ini menggunakan kuesioner yang juga digunakan oleh Wiyantoro (2011) pertanyaan kuesioner pengungkapan akuntansi lingkungan dengan 17 pertanyaan yang terdiri dari 17 skala likert dimana $1=$ SDT (Sangat Tidak Memadai), $2=$ TD (Tidak Memadai), $3=\mathrm{S}$ (Sedang), 4 = M (Memadai), 5 = SM (Sangat Memadai).

\section{Teknik Analisis Data}

Teknik analisis data yang digunakan dalam penelitian ini adalah menggunakan statistik deskriptif, uji asumsi klasik dan uji hipotesis dengan menggunakan uji beda. Sebelum melakukan pengujian data, peneliti melakukan pengujian kualitas data dengan menggunakan uji realibilitas dan uji validitas.

\section{Statistik Deskriptif}

Analisis statistik deskriptif berguna untuk mengungkapkan gambaran suatu data yang dilihat dari nilai kisaran teoritis dan kisaran aktual (Ghozali, 2016). Kisaran teoritis menjelaskan kisaran yang seharusnya antara skor jawaban paling rendah dengan skor jawaban paling tinggi berdasarkan jumlah skala interval dalam kuesioner. Kisaran aktual menjelaskan skor jawaban responden penlitian terendah dan tertinggi (Sugiyono, 2010).

\section{'Uji Kualitas Data}

\section{Uji Validitas}

Dalam penelitian ini alat uji statistik yang dipakai untuk menguji valid atau tidaknya kuesioner adalah Keiser-Meyer-Olkin-Measure of Sampling Adequenci (KMO MSA) dan Anti - Image Matrices. Nilai KMO bervariasi dari 0 sampai 1, nilai yang dikendaki harus besar dari 0,5 serta nilai Anti - Image Matrices harus besar dari 0,6 untuk membuktikan bahwa seluruh item pertanyaan penelitian dianggap valid (Ghozali, 2016). 


\section{Uji Realibilitas}

Pengukuran yang memiliki reliabilitas yang tinggi adalah pengukuran yang dapat menghasilkan data yang reliabel. Dalam uji reliabilitas menunjukkan bahwa instrumen penelitian dengan alat uji statistik Cronbach alpha $(\alpha)$ dimana jika nilai cronbach Alpha $>$ dari 0,07 maka dapat dikatakan reliabel. (Sugiyono, 2013:121).

\section{Uji Normalitas}

Uji normalitas dapat dilakukan dengan Kolomogrov-Smirnov Test. Tes KolomogrovSmirnov dua arah menggunakan kepercayaan 5 persen. Pengambilan keputusan untuk menentukan normal atau tidaknya data yang akan diolah apabila hasil asymp sig (2-tailed) > dari 0,05 maka data tersebut terdistribusi normal, sebaliknya apabila hasilasymp sig (2-tailed) $\leq$ dari 0,05 maka data tersebut tidak terdistribusi normal.

\section{Uji Hipotesis.}

Pengujian hipotesis menggunakan uji beda T-statistik. Jika profitabilitas $>0,05$ maka Ho diterima dan Ha ditolak artinya tidak terdapat perbedaan yang signifikan dalam persepsi antara Akuntan Publik dan Akuntan Pendidik terhadap Konsep Dasar, Pengukuran dan Pengungkapan Akuntansi Lingkungan. Jika profitabilitas $<0,05$ maka Ho ditolak dan Ha diterima artinya terdapat perbedaan yang signifikan dalam persepsi antara Akuntan Publik dan Akuntan Pendidik terhadap Konsep Dasar, Pengukuran dan Pengungkapan Akuntansi Lingkungan

\section{HASIL PENELITIAN DAN PEMBAHASAN}

\section{Deskriptif Sampel}

Responden dalam penelitian ini adalah Akuntan Publik dan Akuntan Pendidik yang ada di Sumatera Barat. Data dikumpulkan dengan menyebarkan kuesioner yang diisi oleh Auditor dan Dosen dengan mendatangi Kantor Akuntan Publik dan Akuntan Pendidik dengan Membagi Link Kuesioner dan menyebar sacara langsung. Penyebaran kuesioner dilakukan selama 25 hari dengan menyertakan persetujuan dari Dekan dan Pembimbing.

Dalam penelitian ini kuesioner yang disebar sebanyak 49 (Dosen) 40 (Auditor) jadi total yang tersebar sebanyak 89 yang memenuhi kriteria pengambilan sampel 62, sedangkan yang tidak memenuhi kriteria sampel ada 7 yang ditolak 20, sehingga didalam penelitian ini hanya terdapat 62 orang yang mengisi kuesioner penelitian yang sudah memenuhi kriteria dalam pengambilan sampel. Tabel 1 menunjukkan karakteristik responden yang berpartisipasi.

\section{Tabel 1. Karakteristik Responden}




\begin{tabular}{|c|c|c|}
\hline & Jumlah & Persentase \\
\hline \multicolumn{3}{|l|}{ Pekerjaan } \\
\hline Akuntan Pendidik & 32 & $51,6 \%$ \\
\hline Akuntan Publik & 30 & $48,4 \%$ \\
\hline Jumlah & 62 & $100 \%$ \\
\hline \multicolumn{3}{|l|}{ Jenis Kelamin } \\
\hline Perempuan & 34 & $54,8 \%$ \\
\hline Laki-Laki & 28 & $45,2 \%$ \\
\hline & 62 & $100 \%$ \\
\hline \multicolumn{3}{|l|}{ Umur } \\
\hline $20-30$ & 34 & $54,8 \%$ \\
\hline $31-40$ & 20 & $32,3 \%$ \\
\hline$>50$ & 8 & $12,9 \%$ \\
\hline Jumlah & 62 & $100 \%$ \\
\hline Pendidikan & 4 & $6,5 \%$ \\
\hline D3 & 20 & $32,3 \%$ \\
\hline $\mathrm{S} 1$ & 26 & $41,9 \%$ \\
\hline $\mathrm{S} 2$ & 12 & $19,3 \%$ \\
\hline \multicolumn{3}{|l|}{ S3 } \\
\hline Jumlah & 62 & $100 \%$ \\
\hline Pengalaman Kerja & 30 & $48,4 \%$ \\
\hline $1-5$ tahun & 15 & $24,2 \%$ \\
\hline 6-10 tahun & 8 & $12,9 \%$ \\
\hline 11-15 tahun & 9 & $14,5 \%$ \\
\hline$>15$ tahun & & \\
\hline Jumlah & 62 & $100 \%$ \\
\hline
\end{tabular}

Berdasarkan Tabel 1 bahwa karakteristik responden dari data di atas menunjukkan bahwa terdapat 62 orang yang menjawab kuesioner dan umur yang paling tinggi adalah pada rentang 20 - 30 dan 31 - 40 tahun sebanyak 20 orang (32,3\%), urutan umur paling rendah adalah umur di atas 50 tahun sebanyak 8 orang $(12,7 \%)$.

Berdasarkan jenis kelamin, yang lebih banyak mengisi kuisioner adalah perempuan yaitu sebanyak 34 orang $(54,8 \%)$ sedangkan Laki - laki berjumlab 28 orang $(45,2 \%)$.Berdasarkan pendidikan, yang paling banyak menjawab adalah S2 yaitu sebanyak 26 orang (41,9\%), selanjutnya S1 sebanyak 20 orang (32,3\%), berikutnya dengan S3 menjawab sebanyak 12 orang $(19,4 \%)$ dan yang sedikit menjawab adalah D3 menjawab sebanyak 4 orang $(6,5 \%)$. Berdasarkan profesi, yang menjawab kusioner berprofesi sebagai Dosen sama banyak dengan yang berprofesi sebagai Auditor yaitu sama sama 31 orang (50,0\%).Terdapat 62 orang yang menjawab, dimana yang paling banyak bekerja yaitu pada rentang $1-5$ tahun sebanyak 30 orang $(48,4 \%)$, selanjutnya yang paling lama bekerja yaitu pada rentang 5 - 10 tahun sebanyak 
15 orang $(24,2 \%)$, selanjutnya pada rentang $>15$ tahun sebanyak 9 orang $(14,5 \%)$, berikutnya yang menjawab pada rentang 11 - 15 tahun sebanyak 8 orang $(12,9 \%)$.

\section{Analisis Deskriptif}

Hasil statistic deskriptif dapat dilihat pada tabel 2

Tabel 2. Statistik Deskriptif

\begin{tabular}{lcccc}
\hline & Kisaran Teoritis & Kisaran Aktual & Mean & $\begin{array}{c}\text { Standar } \\
\text { Deviasi }\end{array}$ \\
\hline $\begin{array}{l}\text { Konsep Dasar } \\
\text { Akuntansi Lingkungan }\end{array}$ & $5-25$ & $10-36$ & 24 & 6.22 \\
$\begin{array}{l}\text { Pengukuran Akuntansi } \\
\text { Lingkungan }\end{array}$ & $18-90$ & $21-90$ & 66,35 & $13,61$. \\
$\begin{array}{l}\text { Pengungkapan } \\
\text { Akuntansi Lingkungan }\end{array}$ & $17-85$ & $21-90$ & 64,11 & $13,88$. \\
\hline
\end{tabular}

Sumber : Olah data penelitian

\section{Uji Validitas Data dan Reliabilitas}

Hasil pengujian validitas dan relianilitas dapat dilihat pada tabel 3.

Tabel 3: Hasil Uji Validitas dan Reliabilitas

\begin{tabular}{lcc}
\hline & KMO & $\begin{array}{c}\text { Cronbach } \\
\text { Alpha }\end{array}$ \\
\hline Konsep Dasar Akuntansi Lingkungan & 0,782 & 0,888 \\
Pengukuran Akuntansi Lingkungan & 0,896 & 0,962 \\
Pengungkapan Akuntansi Lingkungan & 0,899 & 0,977 \\
\hline
\end{tabular}

Sumber : Olah data penelitian

Hasil pengujian Kaiser Meyer Olkin untuk Konsep Dasar Akuntansi adalah 0,782. > dari 0,5 maka data telah valid. Berdasarkan tabel diatas nilai Kaiser Meyer Olkin untuk Pengukuran Akuntansi Lingkungan adalah 0,896 > dari 0,5 maka data telah valid. Berdasarkan tabel diatas nilai KMO dari Pengungkapan Akuntansi Lingkungan adalah 0,899>0,5 maka data telah valid.

Hasil uji reliabilitas Konsep Dasar Akuntansi menunjukkan nilai Cronbach's Alpha sebesar 0,888 > 0,7 maka data telah reliabel pada data tersebut. Untuk variabel Pengukuran Akuntansi Lingkungan didapatkan nilai Cronbach's Alpha sebesar 0,962 > 0,7 maka data telah reliabel. Selanjutnya, untuk variabel Pengungkapan Akuntansi Lingkungan memiliki nilai Cronbach's Alpha sebesar 0,977 > 0,7 maka data telah reliabel pada data tersebut.

\section{Uji Normalitas Data}

Pada penelitian ini untuk menguji data terdistribusi normal atau tidak dengan 
menggunakan uji Kolmogorov-Smirnov test (KS). Data dikatakan berdistribusi normal jika nilai asymp.Sig (2-tailed)> 0,05. Berikut adalah hasil pengujian normalitas pada tabel dibawah ini:

Berdasarkan hasil analisis, variabel Konsep Dasar Akuntansi memiliki nilai Asymp.Sig(2-tailed) sebesar 0,441 yaitu > 0,05 maka data telah terdistribusi normal untuk variabel tersebut. Untuk variabel Pengukuran Akuntansi Lingkungan memiliki nilai Asymp.Sig (2-tailed) sebesar 0,193 yaitu > 0,05 maka data telah terdistribusi normal untuk variabel tersebut. Dan yang terakhir untuk variabel Pengungkapan Akuntansi Lingkungan memiliki nilai Asymp.Sig (2-tailed) sebesar 0,063 yaitu > 0,05 maka data telah terdistribusi normal untuk variabel tersebut.

\section{Uji Hipotesis}

Untuk menguji hipotesis perbedaan persepsi Akuntan Pendidik dan Akuntan Publik terhadap Konsep Dasar, Pengukuran dan Pengungkapan Akuntansi Lingkungan adalah pada nilai $t$-Test for equality of means yang dapat dilihat pada tabel 3:

\section{Tabel 4. Hasil Pengujian Hipotesis}

\begin{tabular}{|c|c|c|c|}
\hline & T Test & $\begin{array}{c}\text { Mean } \\
\text { Akuntan Publik }\end{array}$ & $\begin{array}{c}\text { Mean } \\
\text { Akuntan Pendidik }\end{array}$ \\
\hline Konsep Dasar Akuntansi & 0,000 & 19,54 & 28,45 \\
\hline $\begin{array}{c}\text { Pengukuran } \\
\text { Lingkungan }\end{array}$ & 0,121 & 69,06 & 63,64 \\
\hline $\begin{array}{l}\text { pengungkapan } \\
\text { lingkungan }\end{array}$ & 0,658 & 63,32 & 64,90 \\
\hline
\end{tabular}

Sumber : Olah data penelitian

Hasil pengujian hipotesis 1 yang menyatakan bahwa terdapat perbedaan persepsi akuntan publik dan akuntan pendidik mengenai konsep dasar akuntansi lingkung dapat diterima. Berdasarkan tabel 4 variabel Persepsi Akuntan Publik dan Akuntan Pendidik tentang Konsep Dasar Akuntansi memiliki nilai $t$-test for Equality of Means adalah 0,000 <0,05 dapat disimpulkan hipotesis diterima yang artinya, terdapat perbedaan persepsi Akuntan Publik dan Akuntan Pendidik tentang Konsep Dasar Akuntansi.

Berdasarkan pernyataan Konsep Dasar Akuntansi untuk persepsi Akuntan Publik memiliki nilai mean sebesar 19,54 sedangkan persepsi Akuntan Pendidik memiliki nilai mean sebesar 28,45 artinya persepsi Akuntan Pendidik nilai rata - rata nya lebih besar dari pada Akuntan Publik. Hal ini menunjukkan bahwa Akuntan Pendidik memiliki pemahaman yang lebih tinggi dibandingkan akuntan publik. Hasil penelitian ini sejalan dengan hasil penelitian yang dilakukan Wiyantoro (2011) yang menyatakan bahwa terdapat perbedaan persepsi yang 
signifikan antara akuntan publik dan akuntan pendidik terhadap konsep dasar akuntansi lingkungan. Sama dengan penelitian sebelumnya oleh Tanihitu (2015) dalam Sari dan Nugroho (2017) yang menyatakan bahwa terdapat perbedaan persepsi yang signifikan antara auditor dan dosen terhadap konsep dasar akuntansi lingkungan. Karena menurut Tanihitu (2015) dalam Sari dan Nugroho (2017) mengatakan bahwa secara teori akuntan pendidik lebih memahami akuntansi lingkungan namun ketika di lapangan auditor lebih berpengalaman.

Hasil dari penelitian yang dilakukan oleh Setyo dkk (2015) juga memiliki kesamaan hasil yaitu terdapat perbedaan persepsi antara Auditor dan Akuntan Pendidik tentang Konsep Dasar Akuntansi Lingkungan. Karena dosen dianggap secara teori telah memahami Konsep Dasar Akuntansi Lingkungan dalam proses pembelajaran berdasarkan pemahaman dan pemikiran yang logis menurut teori yang ada (Setyo et al, 2015).

Hasil Pengujian hipotesis 2 yaitu terdapat perbedaan Persepsi Akuntan Publik dengan Akuntan Pendidik terhadap Pengukuran Akuntansi memiliki nilai $t$-test for equality of means adalah 0,121 > 0,05 maka hipotesis ditolak artinya tidak terdapat perbedaan persepsi antara Akuntan Publik dengan Akuntan Pendidik. Dan dilihat dari pernyataan tentang Pengukuran Akuntansi Lingkungan persepsi Akuntan Publik memiliki nilai mean sebesar 69,06 sedangkan persepsi Akuntan Pendidik memiliki nilai mean sebesar 63,64 artinya persepsi Akuntan Publik nilai rata - rata nya lebih besar dari pada Akuntan Pendidik. Hasil ini tidak konsisten berdasarkan penelitian yang dilakukan Wiyantoro (2011), Tanihitu (2015) dan penelitian Setyo et al (2015) yang menyatakan bahwa terdapat perbedaan persepsi yang signifikan antara auditor dan dosen terhadap pengukuran akuntansi lingkungan.

Hasil pengujian hipotesis 3 yang menyatakan terdapat perbedaan Persepsi Akuntan Publik dengan Akuntan Pendidik terhadap Pengungkapan Akuntansi Lingkungan dapat dilihat dari nilai signifikan $t$-test for equality of means adalah 0,658 > 0,05 maka dapat disimpulkan hipotesis ditolak yang artinya, tidak terdapat perbedaan persepsi antara Akuntan Publik dengan Akuntan Pendidik terhadap Pengungkapan Akuntansi Lingkungan

Selanjutnya, dilihat dari pernyataan tentang Pengungkapan Akuntansi Lingkungan untuk persepsi Akuntan Publik memiliki nilai mean sebesar 63,32 sedangkan persepsi Akuntan Pendidik memiliki nilai mean sebesar 64,90 artinya persepi Akuntan Pendidik nilai rata - rata nya lebih besar dari pada Akuntan Publik. Dapat disimpulkan dari pernyataan diatas bahwa persepsi Akuntan Pendidik tentang Konsep Dasar dan Pengungkapan Akuntansi Lingkungan lebih besar dibandingkan dengan persepsi Akuntan Publik. Berbeda dengan Pengukuran Akuntansi Lingkungan dimana persepsi Akuntan Publik lebih besar dibandingkan dengan Akuntan Pendidik. 
Hasil ini mendukung hasil penelitian yang dilakukan Wiyantoro (2011) yang menyatakan bahwa tidak terdapat perbedaan persepsi yang signifikan antara akuntan publik dan akuntan pendidik tentang Pengungkapan Akuntansi Lingkungan, tetapi tidak konsisten dengan hasil penelitian dari Setyo et al (2015) dan Tanihitu (2015) yang menyatakan bahwa terdapat perbedaan persepsi akuntan publik dan akuntan manajemen tentang pengungkapan akuntansi lingkungan.

\section{SIMPULAN}

Penelitian ini bertujuan untuk mengetahui persepsi antara Akuntan Publik dengan Akuntan Pendidik terhadap Konsep Dasar, Pengukuran dan Pengungkapan Akuntansi Lingkungan. Berdasarkan data yang telah dikumpulkan dan hasil penelitian yang telah di uji pada bagian sebelumnya, maka dapat disimpulkan bahwa terdapat perbedaan persepsi antara Akuntan Publik dengan Akuntan Pendidik terhadap Konsep Dasar Akuntansi Lingkungan. Tidak terdapat perbedaan persepsi antara Akuntan Publik dengan Akuntaan Pendidik terhadap Pengukuran Akuntansi Lingkungan dan tidak terdapat perbedaan persepsi antara Akuntan Publik dengan Akuntaan Pendidik terhadap Pengungkapan Akuntansi Lingkungan.

Penelitian ini memiliki keterbatasan yaitu objek penelitian yang hanya meneliti persepsi Akuntan Publik dan Akuntan Pendidik di Kota Padang sehingga hasil penelitian tidak dapat digeneralisasi pada objek yang lebih luas. Penelitian ini hanya menguji perbedaan persepsi mengenai konsep dasar akuntansi, pengukuran dan pelaporan akuntansi lingkungan. Alat analisis yang digunakan menggunakan uji T yang hanya dapat melihat satu tingkatan perbedaan. Oleh sebab itu untuk penelitian selanjutnya disarankan dapat memperluas objek penelitian, menguji faktor lainnya seperti menguji dari sisi Usia, akuntan manajemen dll. Dengan demikian dapat digunakan analisis lebih mendalam seperti penggunaan Teknik analisis ANOVA.

Penelitian ini memiliki kontrisbusi yaitu dapat dijadikan sebagai tambahan literature atau acuan dalam perkembangan ilmu dan teori dari akuntansi lingkungan baik itu Konsep Dasar Akuntansi Lingkungan, Pengukuran Akuntansi Lingkungan dan Pengungkapan Akuntansi Lingkungan. Bagi perusahaan, penelitian ini dapat memberikan manfaat bagi perusahaan mengenai pentingnya pengungkapan akuntansi lingkungan yang harus dilaporkan di laporan keuangan, sebagai bentuk dari manajemen keuangan perusahaan. 


\section{REFERENSI}

Alimbudiono, R. S. (2020). Konsep Pengetahuan Akuntansi Manajemen Lingkungan. CV Jakad Media Publishing. Surabaya.

Arikunto, S. (2010). Prosedur Penelitian: Suatu Pendekatan Praktik Arikunto, Suharsini. (2010). Prosedur Penelitian: Suatu Pendekatan Praktik (Edisi Revisi 2010) (Ed.Rev.201;Suharsimi Arikunto,Ed.) Retrivied from http://library.fis.uny.ac.id/opac/index.php?p=show_detail\&id=2193 diakses pada 5 April 2020.

Agustia, D. (2010). Pelaporan biaya lingkungan sebagai alat bantu bagi pengambilan keputusan yang berkaitan dengan pengelolaan lingkungan. AKRUAL: Jurnal Akuntansi, 1(2), 190214.

Andika, A., Sulindawati, N. L. G. E., Kurniawan, P. S. (2017). Analisis Perlakuan Akuntansi Atas Biaya Pengolahan Limbah Pabrik (Studi Penerapan Akuntansi Lingkungan Pada PT Indocitra Jaya Samudra Jembrana). JIMAT (Jurnal Ilmiah Mahasiswa Akuntansi) Undiksha, 8(2).

Anggraini, Y. (2008). Hubungan antara Environmental Performance, Environmental Disclosure dan return Saham. Skripsi. Universitas Diponegoro.

Aniela, Y. (2012). Peran Akuntansi Lingkungan dalam meningkatkan Kinerja Lingkungan Dan Kinerja Keuangan Perusahaan. Berkala Ilmiah Akuntan Pendidik, Vol.1, No.1, Januari 2011.

Bartolomeo, M., M. Bennet \& J.J. Bouma. (2000). Environmental Management Accounting in Europe Current Practice and Future Potential. The European Accounting Review. Vol. 9, No. 1, pp 31-5.

Burhany, D. (2014). Pengaruh Implementasi Akuntansi Lingkungan Terhadap Kinerja Lingkungan dan Pengungkapan Informasi Lingkungan.Vol.2014: Hal. 1.

Budianty, P. I. (2018). Pengaruh Pengungakapan Akuntansi Lingkungan, dan Corporate Sosial Resposibility (CSR) Terhadap Kinerja Keuangan. Jurnal Universitas Islam Negeri Sultan Syarif Kasim Riau.

Charim. (2020). PT. Jaya Media Internusa Diduga Buang Limbah Tanpa IPAL. https://www.lensahukum.co.id/read/19548/pt-jaya-media-internusa-diduga-buanglimbah-tanpa-ipal/

Dimyati, M. (1990), Psikologi suatu pengantar, BPFE, Yogyakarta.

Felisia, A. L. (2014). Triple Bottom Line and Sustainability. Jurnal Fakultas Ekonomi Universitas Katolik Parahyangan. Vol. 18, Nomor 1 (Januari).

Ghozali, I. (2016). Aplikasi Analisis Multivariete dengan Program IBM SPSS 23.

Handayani, A. R. (2010). Pengaruh Environmental Performance Terhadap Environmental 
Disclosure Terhadap Economic Performance (Studi Empiris Pada Perusahaan Manufaktur yang Terdaftar Di Bursa Efek Indonesia). Skripsi. Universitas Diponegoro.

Handriansyah, H. (2020). Buang Limbah ke Citarum, Sedikitnya 4 Saluran Pembuangan Milik 2 Perusahaan di Cisirung Disegel. https://www.pikiran-rakyat.com/bandung-raya/pr01638701/buang-limbah-ke-citarum-sedikitnya-4-saluran-pembuangan-milik-2perusahaan-di-cisirung-disegel

Hansen \& Mowen. (2007). Management Accounting. Edisi 8. Penerbit Salemba Empat.

Hendriksen, E.S \& V.B., Micheal. (2002). Teori Akuntansi. Edisi Kelima. Buku Dua. Penerbit Interaksara. Batam Centre.

Idris. (2012). Akuntansi Lingkungan Sebagai Instrumen Pengungkapan Tanggung Jawab Perusahaan Terhadap Lingkungan di Era Green Market. Universitas Negeri Padang.

Ikhsan, A. (2008). Akuntansi Lingkungan dan Pengungkapannya. Penerbit Graha Ilmu, Cetakan Pertama.

Kumalahadi. (2000). Perspektif Pragmatik:Lingkungan dan sosial dalam laporan keuangan. JAAI Vol. 4, No.1 (Juni).

Kusumaningtyas, R. (2013). Green Accounting, Mengapa dan Bagaimana?. Proceeding Seminar Nasional dan Call of papers Sancall. Surakarta (Maret).

Nagoro, S. D. S. (2015) Persepsi Auditor, Akuntan Pendidik, Akuntan Manajemen dan Mahasiswa Tentang Konsep Dasar, Pengukuran Dan Pengungkapn Akuntansi $\quad$ Lingkungan. Skripsi. Fakultas Ekonomi UNISSULA

Nursamsiah, A. (2019). Pengaruh Implementasi Akuntansi Lingkungan terhadap Kinerja Perusahaan. Jurnal Saintik ManajemenVol. 02, No. 02, 2019.

Parmawati, R. (2019). Valuasi Ekonomi Sumberdaya Alam dan Lingkungan Menuju Ekonomi Hijau. UB Press. Malang.

Puspita, G. (2014). Analisis Perbandingan persepsi Mahasiswa Akuntansi Mengenai Perilaku Etis Akuntan. No.Daftar FPEB :520/UN.40.7.D 1 Universitas Pendidikan Indonesia.

Paskah I. N., Devina R. S., \& Nugroho. (2017). "Persepsi Akuntan Pendidik terhadap Konsep Dasar, Pengukuran dan Pengungkapan Akuntansi Lingkungan", Jurnal Akuntansi Vol.9 No.1 Mei. Maranatha

Putri, R. D. (2019). 11 Perusahaan Perusak Lingkungan Rugikan Negara Rp18 Triliun. https://tirto.id/11-perusahaan-perusak-lingkungan-rugikan-negara-rp18-triliun-dgZ6.

Rusmana, O. (2003). Sikap dan Niat Akuntan terhadap internalisasi informasi lingkungan dalam sistem akuntansi perusahaan. Universitas Jendral Sudirman Purwokerto. Simposium Nasional Akuntansi VI. Surabaya (Oktober) 16-17. 
Sadjiarto, A. (2011). Pelaporan Aktivitas Lingkungan dan Akuntansi Lingkungan. In: Seminar Nasional dan Call for Papers Lingkungan Hidup 2011 "Living Green: Mensinergikan Kehidupan, Mewujudkan Keberlanjutan”. Petra Christian University. Surabaya.

Santoso, H. (2012). Akuntansi Lingkungan Tinjauan Terhadap Sistem Informasi Akuntansi Manajemen atas Biaya Lingkungan. Jurnal Akuntansi Vol. 12, No. 2, November 2012: 635-654

Supheni, I. (2016).Implementasi Akuntansi Lingkungan dalam Pelaksanaan CSR Pada Pabrik Gula Lestari. Jurnal Cendekia Akuntansi Vol. 4 No. 2, Mei 2016

Sari, D. dan Nugroho P. I. (2017). Persepsi Akuntan Pendidik terhadap Konsep Dasar, Pengukuran dan Pengungkapan Akuntansi Lingkungan. Jurnal Akuntansi Vol.9, No.1. Mei 2017: 34 - 53.

Sambharakreshna, Y. (2009). Akuntansi Lingkungan dan Akuntansi ManajemenLingkungan : Suatu Komponen Dasar Strategi Bisnis. Jurnal Infestasi Vol. 5, No. 1, Juni 2009. Hal. $1-21$.

Suartana, I.W. (2010). Akuntansi Lingkungan dan Triple Bottom Line Accounting: Paradigma Baru Akuntansi Bernilai tambah. Jurnal Bumi Lestari. Vol.10 No.10, pp 105-112.

Sugiyono (2013). Metode Penelitian Pendidikan Pendekatan Kuantitatif, Kualitatif, dan R\&D. $2013 \mathrm{Hal}: 121$

Sekaran, U. (2006). Metodologi Penelitian Untuk Bisnis (Buku 1). Salemba Empat.

Tanihatu, (2015). Persepsi auditor dan akuntan pendidik terhadap konsep dasar akuntansi lingkungan, pengukuran akuntansi lingkungan, dan pengungkapan akuntansi lingkungan. Benchmark journal. Maret 2015.

United States Environmental Protection Agency (USEPA). 1995a.An Introduction to Environmental Accounting as a Business Tool: Key Concepts and Term USEPA Washington DC.

Wiyantoro, L.S., A.S Yulianto., M. Muchlis., \& D. Ramdhani. (2011). Persepsi auditor, akuntan pendidik dan akuntan manajemen tentang konsep dasar, pengukuran dan pengungkapan akuntansi lingkungan. Simposium Nasional Akuntansi XIV.

Yulianthi, A. (2018). Model Penerapan Akuntansi Lingkungan Sebagai Bentuk Tanggung Jawab Perusahaan di Era Green Tourism Accounting. Jurnal Bisnis dan Kewirausahaan, Vol. 14, No. 3.

Zubaidah, S., \& Zulfikar. (2005). Pengaruh Faktor-Faktor Keuangan dan Non Keuangan Terhadap Pengungkapan Sukarela Laporan Keuangan. Jurnal Riset Akuntansi Indonesia. Vol. 4, No. 1. April:48-83 